UDC 371.26

DOI https://doi.org/10.32840/1992-5786.2021.74-1.34

\author{
L. H. Yaroshchuk \\ Candidate of Pedagogical Sciences, \\ Associate Professor at the Department of Pedagogy \\ Berdyansk State Pedagogical University
}

Yu. S. Vaseiko

Candidate of Philological Sciences, Associate Professor at the Department of Polish Studies and Translation Lesia Ukrainka Volyn National University

\title{
MONITORING AND PEDAGOGICAL CONTROL IN THE EUROPEAN SYSTEM OF EDUCATION
}

The article discusses the international research of educational quality in the countries of the European Union at the present stage. As an example of monitoring at international level there can serve the implementation of the international programs (TIMSS, PISA, PIRLS, CIVIC, LINGVA etc.) carried out with the support of International Association for the Evaluation of Educational Achievements (IEA) and Organization for Economic Cooperation and Development (OECD). There have been brighten up the variables affecting the results of the tests of those being tested.

The international comparative researches provide identifications with not only positive aspects but also shortcomings of educational programs. Besides, on the basis of their results (information) the central educational bodies can apply tools which promote raising achievement of pupils, productivity of activity of teachers and overall performance of school institutions in general. At the same time, according to the international monitoring, it is possible to track the development of education in any country if the management of educational systems is decentralized.

The authors prove that the latest developments in the field of monitoring are among the countries that make extensive use of France, Greece, Italy, Switzerland, Great Britain, the Netherlands, Denmark, Germany, etc. belong to the countries which widely use the last achievements in the sphere of monitoring, they have developed the classical theory of tests, then provided IRT and the based practice of testing for millions of pupils, organized the companies and services which develop tests, organize mass testing, are constantly engaged in collection of information for monitoring of quality of education. Experience of the western countries shows that they are ahead of us on scales of application of tests, the number of publications, preparation of scientific resources, level and quality of the theory of test techniques and control, modern technical means which are used in testing.

Monitoring of school progress which took stable positions in the educational systems of the developed countries for the last decades gives an opportunity to obtain data on a condition of an educational system in the country. According to scientists not too many countries have accurate information on the level of knowledge of pupils. France, Great Britain are interested not only in the results of knowledge of pupils but also process of assimilation of knowledge and how to help pupils who have difficulties at school. Confirmation of the importance of this problem is an introduction in the European countries, in particular in Great Britain and France, of special training for teachers in estimation of knowledge of pupils - a course of a new discipline in higher educational institutions.

Key words: monitoring, international comparative studies, quality of education, educational systems, testing, tests, testology (testing appraisal), study results.

Introduction. History of development of pedagogical control has so many years as pedagogical activity exists. Every teacher from ancient times always measured a result of the educational process. Since the period of ancient Babylon, Egypt, China, India, Greece people were tested, diagnostics of different capabilities were carried out, physical and mental qualities were estimated.

Scientists have proved that the first tests appeared a few millenniums back in Ancient China. One of the first systems of objective selection was created three thousand years BC in order to choose the most decent people for the court service among others. There was the system of verification of capabilities of those who wished to hold positions of governmental officials in this country yet for 2200 years BC. Every three years officials were repeatedly tested personally for an emperor in six "arts": music, archery, riding, writing, counting, knowledge of rituals and ceremonies. The system of examinations was the important mean of selection sufficiently of capable, erudite and, mainly, loyal to power people for their subsequent use on administrative service. Except for it, the behavior in the household was estimated as well. The similar system was used for the selection of officers for the creation of an army in Vietnam. 
This system became complicated and advanced with the development of state structures. Since 202 $\mathrm{BC}$ during the reign of Khan Dynasty the examinations were added to the system of selection of officials. Applicants on administrative position necessarily should know a law, military business, finances, agriculture and geography [3, p. 19].

In the Orient writing test papers and examinations were considered normal and natural since ancient times. In ancient Egypt the system of tests was used for interview and subsequent verification of abilities. In ancient Greece tests included (for example, at school of Pythagoras) special mathematical tasks of the high level of complication. Ancient Chinese used the first professionally-oriented tests for applicants on the position of a governmental official (those, who complete test with the best results, become accepted on government service). In ancient India the wisdom test was applied by different games, for example, with the use of chess. In ancient Vietnam the regular certification and re-certification of all civil officials and servicemen was conducted on the regular basis [5, p. 31].

A professionally prepared clerk was the central figure of Mesopotamian civilization due to knowledge. He was obliged to know all four arithmetic operations, be able to measure the fields, distribute rations, divide property, and possess the art of singing and playing the musical instruments [4, p. 4].

In Ancient Egypt only that was accepted to the studies the art of priest, who was able to survive the system of certain tests. At first, a candidate for a priest had interview, which described his biography, level of education. An appearance and ability to conduct conversation were estimated. Abilities to work were then checked up, to listen and be quiet; to overcome fire, water, fear, independently escape from dark caves and other obstacles. All these cruel tests were complemented with threat of death for those who were not sure of the abilities to train and manage to sustain the long period of education. This severe system of tests was successfully completed by the famous scientist Pythagoras. Having returned later to Greece, he founded a school. Only those who were capable to overcome a series of various tests were allowed to enter the school. As historical sources testify, Pythagoras emphasized the important role of mental abilities, claiming that "it is possible to turn Mercury not from each tree" and therefore probably provided great value to diagnostics of these abilities. For this purpose, everyone had a comparatively difficult mathematical task. If the applicant met the challenge he was enrolled at once. However, most often they did not cope with tasks then the loser was entered into the hall where pupils by rules of tests had to ruthlessly embarrass him, giving offensive nicknames. If the behavior of the beginner in this critical situation was characterized by responding to insults, to behave well and adequately, that one was accepted to school [1].
Pythagoras gave special value to laugh errand the gait of young people, claiming that the manner of laugh hinges' the best indicator of the character of the person.

The results of mental abilities tests became a subject to people's pride and sometimes even earnings. It is known, for example that the Indian tsar Devsarm, wishing to test the wisdom of Iranians, sent them chess. It was supposed that Iranian swill hardly manage to solve the essence of the game and therefore they had to send taxes to India. However, the vizier Khosrowa Vazhurgmikhr understood rules of the game and, in his turn, invented a game which we call "backgammon" today. He sent vizier to India where the game could not be solved. Materials that teach bases religious doctrine of Chan Buddhism are other evidence of the use of tests. Chan Buddhism teachers used riddles, a riddle question with simultaneous creation of a situation of psychological stress. It was necessary to answer immediately; there was no time for reflections. In Chan duels dialogues contained the paradoxicality of statement of questions (for example whether bearded barbarian had a beard or whether the dog had Buddha's nature), created dramatic tension which was aggravated with all actions of the mentor. He grabbed a sleeve of a challenger and shouted: "Speak! Speak! Answer immediately!". He created a situation of mental tension. Paradoxical riddles were used as tests for measurement certain "chan" thinking. The experienced mentor defined at what enlightenment level neophyte was and what measures need to be taken for deepening of "chan experience". Besides, detected simulators hid the incompetence beyond external impudence and rough behavior [1].

Various competitions and examinations were organized also in the medieval Vietnamese state. In only two years since 1370 by 1372 recertification of all military and civil officials was carried out successfully and later that allowed organizing of checking government in the whole country. As a result, Vietnam became a strong and viable feudal state. Special attention was paid to the creation of the efficient officer case. In the 15th century competitive tests were arranged. They were carried out on stages and tours. The assignment of the highest steps at examinations was followed by big honors. Winners received gifts from the king, their names were included in "the gold list" which hung above the eastern gate of the capital, the native communities had the report about winners. Names of the cleverest were cut on the special stone walls set in the Temple of literature [1].

The physiognomics - art of recognition of character and abilities of the person according to appearance was a popular form of diagnostics of abilities of the person that days. Hippocrates used this term for the first time and considered physiognomics to be 
a science. This short historical digression approves that testing methods in ancient times were primitive. In many countries of the world testology is developed as the science that is why there is the whole system of testing of the personality: whether it is a future worker or student, military or government employee. It is necessary to pass tests of two types while entering the educational institution or employment. Usually it is national and personal psychological tests.

The international comparative monitoring researches in the field of education are conducted in the world since the $1970 \mathrm{~s}$. The purpose of such research is an integration of international experience, identification and the analysis of perspective trends into the fields of education, development of recommendations for the countries participating in comparative researches. Use of evidence-based criteria for determination of quality of educational process, a wide range of member countries (Ukraine, having joined the Bologna declaration on May 2005, became the 45th participant of Bologna Process) gives each of them the chance to estimate real achievements of domestic education against the background of world achievements, to join the best experience of creation of effective technologies of training and to use them for improvement of own educational practice.

Thanks to special tools it is possible to measure and estimate qualitative characteristics that are inherent for the particular person whom also the level of knowledge belongs. Such tools were created within the last century, and still being improved. It is about testology as the industry of scientific research that is engaged in measurement and estimation of abilities of the person [2, p. 134].

The testing method is widely used in the European countries: Germany, Sweden, Norway, Great Britain, France. In Ukraine tests are applied not only during the examinations. Therefore, the main objective of the higher school is the formation of abilities of control, assessment and monitoring of quality of education with use of test technologies for future teachers. Only when the teacher is guided rather freely in questions of educational measurements, our state can receive the advanced personality who will adequately represent our people in world space after leaving school $[9$, p. 5].

From the second half of the 20th century in Europe the special commissions began to develop the international programs of a research of student's knowledge which give the chance to determine the level of knowledge of pupils for each country separately, to provide comparisons at the international level, to reveal how effectively each educational system functions. Monitoring at the international level is provided thanks to the international programs (TIMSS, PISA, PIRLS, CIVIC, LINGVA etc.) that are carried out with the assistance of the International association according to educational achievements (IEA) and the Organization for economic cooperation and development (OECD). But these programs originate for a long time. Let's try to clear the history of the emergence of monitoring researches.

The works of V. Avanesov, V. Andreyeva, And. Bulah, N. Efremova, V. Kadnevsky, V. Kym, O. Lokshina, A. Mayorov, A. Permyakova, N. Samilkina, L. Figurska, etc. are devoted to the issue of Monitoring researches in Europe.

The purpose of this article is the analysis of carrying out of the present international researches of quality of training in the countries of the European Union.

Discussion. Testing for the first time was used by J. Fischer for check of level of knowledge of pupils by means of scale books which appeared in 1864 in Great Britain. These books can be considered the first samples of school performance tests. Theoretical bases of testing were developed later in 1883 by English psychologist F. Galton who is often called the ancestor of testing. "A research of human abilities and their development", the work of F. Galton defines testing as method in which identical experiences of rather large number of individuals with statistical processing of results and definition of standards of assessment are applied [1, p. 75].

Modern testing is usually reckoned from the tests developed by A. Bine and T. Simon by request of the Ministry of Education of France for the children selection. It was required for special schools where pupils with mental retardation were taught. The increased growth of interest in tests and testing appeared recently in many countries with the purpose to support the state level of the general education (for example, in Germany, France, Austria, and other countries) [9, p. 34].

There is a whole system of testing of the personality in different countries: for the future worker or student, military or government employee. Mainly in the countries where testology is developed as science (in Germany, England, France, Austria, the Netherlands, Sweden, Switzerland, Great Britain, etc.), admission to educational institution while applying for a job it is necessary to pass tests of two types. Usually, it is national and personal psychological tests.

For example, to enter the German school, the school student has to pass introductory tests and have an interview. The foreign citizen who applies for nationality in Germany has to pass a test for knowledge of German, the test for knowledge of laws, public order and life in Germany.

For those citizens who want to work in public services of Germany psychologists study specific features even including religious position of the applicant by tests [9, p. 36].

The period before the development of monitoring of quality of education lasted until the beginning of 
the 20th century. The classical period of development of monitoring of quality of education proceeded from the 1930th until the end of the 1970th years and was very productive in the countries of the West.

The analysis of scientific sources demonstrates that introductions of comparative researches of descriptive character were used in the 60s years of the 20th century in many countries of the world. The standardized testing in the main objects is held at different steps of training and in different age groups. In the majority of the international comparative researches pupils at the age of $9-10,13-14$ and 17-18were tested [6, p. 227].

Researches of assessment of quality of mathematical and natural-science education (TIMSS) belong to the major international researches of estimation of quality of secondary education which were carried out in the second half of the 20th century by the International program of assessment of knowledge and abilities of pupils (PISA).

International research, TIMSS was carried out in 1994-1995 and has a great value. The purpose was supposed to determine the level of natural and mathematical training of pupils at the different levels of school (5 parallels): 3-4 classes elementary, 7-8 classes main and graduation class of high school. TIMSS is considered one of important monitors of quality of education which was carried out for comparison natural and mathematical training of pupils in the countries with different education systems and also identifications of factors which influence the level of proficiency of school students. The purpose of testing was also to check educational achievements of pupils during performance of practical tasks. The received results of testing give the chance to compare the level of mathematical training of pupils in the different countries according to requirements of the international test. The results of testing have shown the best indicators of the studying natural science. Pupils succeeded in such European countries: the first place - Czech Republic (574 points), the Netherlands (560 points), Slovenia (560 points), Austria (558 points). The second group included only 16 member countries. Hungary (554 points), Great Britain (552 points), Germany (531 points), etc. Switzerland, Spain, France, Denmark, and other countries according to the results of testing are on the third position, (their average points were $552,517,498,478)[6$, p. 227-228].

The international comparative researches provide identifications with not only positive aspects but also shortcomings of educational programs. Besides, on the basis of their results (information) the central educational bodies can apply tools which promote raising achievement of pupils, productivity of activity of teachers and overall performance of school institutions in general. At the same time, according to the international monitoring, it is possible to track the development of education in any country if the management of educational systems is decentralized [6, p. 229].

According to A. Lokshina, the efficiency of functioning of an education system of each country can be determined only by results that it produces (achievements of pupils in the most important disciplines, the number of pupils who took final examinations, vocational training, etc.) [6, p. 229].

We agree with A. Permyakova's opinion about the course of preparation for carrying out the international comparative researches in the countries which pupils took part in testing organized for national groups of researchers who had access to the international network of experts to the fields of education and developed estimation models taking national peculiarities into account. In these states the national centers were created for research that is the testimony of importance of a question of school education, in particular qualities of training of pupils.

The network of the research pedagogical centers was created in countries of Western Europe at the end of the 20th century. There were about 2 thousand institutions of this kind only in Germany. The Center of pedagogical documentation and programming (DPD) was created in France, Community of pedagogical researches worked in Great Britain. Coordination of pedagogical researches was carried out by the following international centers: the International institute of pedagogical researches (Germany), the International pedagogical center (France), the Center of researches of comparative pedagogics (Great Britain), etc. Comprehensive preparation for participation in the international research, expert activity, processing of results of the testing, analyzing results of a comparative research and their lighting at the state level was the purpose of these authorities [6, p. 220].

We agree with the opinion of scientists that Great Britain is a classical example of the diagnostic standardized estimation. The main objective of diagnostic standardized estimation which is applied in this country is a check of level of knowledge assimilation, the skills provided by the educational standard (National Curriculum) therefore, its estimations are obligatory for all pupils and are carried out at the end of the academic year. Standardized estimations are conducted with the diagnostic purpose in defined stages: Elementary school at the age of 7 - in English (reading, writing, a calligraphy, spelling) and mathematics; Elementary school at the age of 11 - English (reading, writing, spelling), mathematics and natural science; the main school (14 years) - English (reading, writing, the analysis of W. Shakespeare's plays), mathematics and natural science. The fourth stage of external estimation is carried out for the purpose of certification [5, p. 134].

Diagnostic estimations are also obligatory for all pupils in France. However, external diagnostic 
estimation which is carried out in general educational institutions of this country has certain features; it is held at the beginning of academic year [5, p. 135]. The first stage of external diagnostic estimation in French and mathematics is carried out at the beginning of the 3rd year at elementary school at the age of 8 . The following - at the beginning of the 1 st year at the main school (college) at the age of 11 years: testings - in French and mathematics. During the move to high school (lyceum) at the age of 16, at the beginning of the 1st year diagnostic estimations on French, mathematics, history or geography, the first foreign language are taken. A positive aspect of this estimation is that teachers obtain at the beginning of academic year not only information about the level of knowledge of pupils with whom they will work further, but also have an opportunity to take measures (if there is a need) for improvement of a situation with student's educational achievements.

The estimation is taken among pupils after completion of the 3rd class of college and is not obligatory as it has no diagnostic direction, and provides only certification. Pupils receive the certificate ("brevet d'étude") about the ending of college.

A significant amount of the countries (France, Great Britain, Germany, Austria, the Netherlands, etc.) supported the development of educational standards and implementation of constant monitoring of the quality of training of school students for more than decades. Thus, France, the country of the centralized traditions, implements the educational activity according to state programs, directed to specifying pupils, parents and all participants of educational process priorities in the study. Besides, monitoring, in the country, plays an important role in the orientation of French school students. As publications of the main educational inspection of France (deals with issues of the studying performance) testify, indicators of school education in the country remain stable for a long time [5, p. 135].

Monitoring of school progress which took stable positions in the educational systems of the developed countries for the last decades gives an opportunity to obtain data on a condition of an educational system in the country. According to scientists not too many countries have accurate information on the level of knowledge of pupils. France, GreatBritain are interested not only in the results of knowledge of pupils but also process of assimilation of knowledge and how to help pupils who have difficulties at school. Confirmation of the importance of this problem is an introduction in the European countries, in particular in Great Britain and France, of special training for teachers in estimation of knowledge of pupils - a course of a new discipline in higher educational institutions [5, p. 135].

Each country of Europe has ancient specific traditions; however, the quality remains a key indicator of the success of a school.
Independent testing as a school final examination was applied for the first time in Europe in 1788.

The data of the international research of natural and mathematical formation of TIMSS-R specifies that the majority of the countries holds state exams by external testing which are available in an electronic resource osvita.ua [8]. For 16 countries of the world, in particular Australia, England, Bulgaria, Italy, Slovenia, Hungary, Finland, such testing performs double function: final and entrance examination. It is also possible to add Germany and France where the results of final examinations are also the basis for accepting at the university. In some countries external testing has ancient tradition. For example, in Great Britain it has been applied more than fifty years, in Poland - more than 10 years. The system of external testing is actively represented in Azerbaijan, Kazakhstan, Kyrgyzstan, Lithuania, Latvia, the Netherlands, Georgia in recent years. The system of testing also works in all countries of Bologna Process.

There is a set of options of holding external final examinations in the European countries: from examination in one subject that is carried out in Great Britain, to Germany's 3 and 12 subjects in Denmark; from introduction only of a written form of external examination in Finland, Bulgaria, Lithuania and in Cyprus to passing such examination in two forms - written and oral that is characteristic of the vast majority of the European countries [8].

Tests are carried out by independent organizations in England. Everybody who wishes to enter higher educational institutions can take part in testing. It takes 9 hours as the English examinations cover a large amount of material, and check assimilation at high level. The main objective of external estimation in Great Britain is a check of the level of knowledge and skills monitored by the state educational standard (National Curriculum). For this reason, given estimations are obligatory for all pupils. The scheme is established by the law to determine eight levels of achievement on the main aspects of each subject. Pupils have to pass each level in two years. 7 -year-old has to reach the second level, 11 - the fourth, and 14-year-old - the fifth or sixth. Thus, Great Britain is a classic example of the use of the diagnostic standardized estimation [8].

French model of external estimation is different from others. It occurs at the beginning of the academic year, is carried out by subject teachers and is obligatory for all pupils. All examinations take place on the basis of school as they are an integral part of secondary education. At the age of 8 and 11 pupils have to pass tests in French and mathematics, and at the age of 16 geography, history and a foreign language are added to these two subjects. It should be noted that in France examinations perform a double role: they are used at the same time as both final school examination and entering [8]. 
The main feature of the Dutch experience of external estimation is its voluntariness. Results of estimation are the basis for receiving a picture of the level of educational achievements of pupils and the projection of the choice of the further direction. Despite all the voluntariness, testing is held in more than $80 \%$ of all Dutch schools.

The Ministry of Education invites National Institute of pedagogical measurement (CITO) to develop national examinations tests. Many schools use these standardized tests which are developed for comparison of results according to national standards. External estimation in the Netherlands is conducted after the ending of elementary school at the age of 12 and after the second stage of secondary education - at the age of 16-18 the certification examinations are held [7].

The system of external obligatory estimation of educational achievements for pupils of 14 and 16 years was introduced for the first time in Poland in 2002. The task was developed for testing by the central examination committee that is an independent body. They were aimed at the measurement of pupils' skills level, but not subject knowledge. All graduates took school final examinations which results were accepted then by all higher education institutions of Poland as entering, therefore, higher educational institutions of Poland do not hold own entrance examinations.

According to the researches of the international experience on final exam system - entrance examinations, the fact that the instrument of objective estimation of educational achievements is external estimation which technology is similar in all countries, and the greatest difference consists only of the contents of tests.

Besides, the electronic edition osvita.ua submitted the generalized data on the organization, results and further use of results of school testing in the European Union countries. 27 member countries of the European Union and 3 countries of the European Economic Area (Iceland, Norway, and Liechtenstein) took part in the research.

In EU countries school testing is the standardized examination in several subjects at certain stages of school training - is one of measuring instruments of quality of education and structuring of the European educational system in general. The research deals with the tests of three types:

- The tests checking the knowledge of pupils at a certain stage also have a significant effect on their academic future (so-called final tests, summative tests. Latvia, Hungary, Austria, and Great Britain give preference to such tests).

- Tests which purpose is monitoring and assessment of a certain school or a school system in general and which can be the basis for changes in a system (common for Estonia, Ireland, Spain, France, Lithuania, Romania, Finland).
- Tests which help to reveal individual needs of pupils for the educational process (so-called formative tests, are carried out in Denmark, Ireland, France, Luxembourg, Hungary, Sweden, Great Britain (England and Scotland), Iceland, Norway) [8].

Contents and structure of tests have to be varied depending on their purposes; however, the research of Eurydice network demonstrates that in the majority of EU countries the same tests are used both for assessment of individual progress of the pupil, and for assessment of quality of school education in general and making of educational decisions at the local, state and international levels.

On average the European countries have school tests three times during all terms of academic year. However, this indicator varies from country to country. For example, in Denmark pupils take up to 11 tests during year, in Scotland and on Malta - up to 10 , in Great Britain - up to 7, in France - up to 6 . In most cases they are obligatory; when selective testing takes place, the more pupils are called for passing.

At the countries of the European Union school testings are covered by two main subjects of the training program - the native language and mathematics; in certain cases, the foreign language joins them. The exception is made by tests for obtaining certificates at the end of the school year. The results of these tests affect the further academic fate of graduates of schools, however, taking into account the extracted school points and internal school estimation.

The majority of the European countries do not publish final ratings of school testing. Sometimes official documents directly forbid the creation of rating tables of schools as a similar technique of estimation of the quality of education is considered inefficient. School institutions obtain data according to the results received by the corresponding to situations at other schools of the country, and the recommendation to analyze and further consideration of this material [8].

Conclusions. Results of the conducted research allow to claim that France, Greece, Italy, Switzerland, Great Britain, the Netherlands, Denmark, Germany, etc. belong to the countries which widely use the last achievements in the sphere of monitoring, they have developed the classical theory of tests, then provided IRT and the based practice of testing for millions of pupils, organized the companies and services which develop tests, organize mass testings, are constantly engaged in collection of information for monitoring of quality of education. Experience of the western countries shows that they are ahead of us on scales of application of tests, the number of publications, preparation of scientific resources, level and quality of the theory of test techniques and control, modern technical means which are used in testing. 


\section{References:}

1. Булах I.€. Комп'ютерна діагностика навчальної успішності. Київ : ЦМК МОЗ України, УДМУ, 1995. $221 \mathrm{c}$.

2. Булах І.Є., Мруга М.Р. Створюємо якісний тест. Київ : Майстер-клас, 2006160 с.

3. Ефремова Н. Тестовый контроль в образовании. Москва : Университетская книга, Логос, 2007. С. 69-78.

4. Міжнародна практика зовнішнього тестування. URL: http://osvita.ua/test/test_article/1865/.

5. Пермякова О.Г. До питання про вимірювання успішності учнів та диференційний підхід до навчання в загальноосвітніх закладах Європи у контексті європейських традицій (друга половина XX століття). Вісник Національної академії Державної прикордонної служби України. Педагогічні науки, 2011. № 2. С. 125-135.
6. Пермякова О.Г. Моніторинг якості навчання в європейських країнах у контексті міжнародних порівняльних досліджень (друга половина XX століття). Наукові записки Тернопільського національного педагогічного університету імені Володимира Гнатюка, 2011. № 2. С. 225-230.

7. Фігурська Л.В. Становлення та розвиток тестування як методу педагогічної діагностики. Народна освіта : електронне наукове фахове видання. URL: http://archive.nbuv.gov.ua/ejournals/NarOsv/2009-1/09flvmpd.htm.

8. Шкільне тестування у країнах $\in C$. URL: http://osvita.ua/test/test_article/4899/.

9. Ярощук Л.Г. Основи педагогічних вимірювань та моніторингу якості освіти : навчальний посібник. Київ : Слово, 2010. 304 с.

\section{Ярощук Л. Г., Васейко Ю. С. Моніторинг та педагогічний контроль в європейській системі освіти}

У статmі розглянуто проведення міжнародних досліджень якості навчання в країнах Європейського Союзу на сучасному етапі. Прикладом моніторингу на міжнародному рівні є впровадження міжнародних програм (TIMSS, PISA, PIRLS, CIVIC, LINGVA тощо), які проводяться за сприяння Міжнародної асоціації з оцінки навчальних досягнень (IEA) і Організації економічного співробітництва та розвитку (OECD). Висвітлено фрактори, які впливають на результати показників успішності тестованих, проведено ретроспективний огляд питання.

Міжнародні порівняльні дослідження передбачають виявлення не лише позитивних моментів, а й недоліків в освітніх програмах. Крім того, на основі їх результатів (інформації) центральні органи освіти можуть застосовувати інструментарій, який сприятиме підвищенню успішності учнів, продуктивності діяльності вчителів та ефрективності роботи шкільних закладів загалом. Разом із тим за даними міжнародного моніторингу можна простежити за процесом розвитку освіти в будь-якій країні, якщо управління освітніми системами є децентралізованим.

Моніторинг шкільної успішності, який в останні десятиріччя зайняв стабільні позиції в освітніх системах розвинутих країн, дає можливість отримувати дані про стан освітньої системи в країні. За твердженням науковців нині доволі незначна кількість країн має чітку інформацію про рівень знань учнів. У Франції, Великій Британії цікавляться не лише результатами знань учнів, а й процесом засвоєння знань, як допомогти учням, у яких є труднощі в навчанні. Підтвердженням важливості цієї проблеми є введення в європейських країнах, зокрема у Великій Британії та Франції, спеціальної підготовки вчителів з оцінювання знань учнів - курсу нової дисципліни в освітніх закладах.

Авторами доведено, що до країн, якішироко використовують останні досягнення усфері моніторингу, належать Франція, Греція, Італія, Швейцарія, Великобританія, Нідерланди, Данія, Німеччина та ін. Вони розвинули класичну теорію тестів, потім запровадили IRT і засновану на ній практику тестування мільйонів учнів, організували компанії та служби, які розробляють тести, організовують масові тестування, постійно займаються збором інформації для моніторингу якості освіти.

Досвід західних країн показує, що вони випереджають нас за маситабами застосування тестів, кількістю публікацій, підготовкою наукових кадрів, рівнем і якістю теорії тестових методик $i$ контролем, сучасними технічними засобами, які використовують під час тестування.

Ключові слова: моніторине, міжнародні порівняльні дослідження, якість навчання, освітні системи, тестування, тести, тестологія, результати успішності. 